\title{
Pengetahuan Orang Tua Terhadap Antioksidan dan Radiasi Pengion Alam (Radon) pada SDN Desa Arjasari Kecamatan Arjasari Kabupaten Bandung
}

\author{
Azhari $^{1}$, Ivhatry R.O.P.S ${ }^{2}$, Merry $A^{1}$, Suhardjo $S^{1}$ \\ ${ }^{1}$ Departemen Dentomaksilofacial Radiologi, Fakultas Kedokteran Gigi,Universitas Padjadjaran \\ ${ }^{2}$ Magister Ilmu Kedokteran Dasar, Fakultas Kedokteran, Universitas Padjadjaran \\ *Email: azhari@fkg.unpad.ac.id \\ Doi : https://doi.org/10.30787/gaster.v17i2.405 \\ Received: April 2019 | Revised: Mei 2019 | Accepted: July 2019
}

\begin{abstract}
ABSTRAK
Latar belakang;Kesadaran dan persepsi radon telah menjadi masalah kesehatan publik dan lingkungan selama setidaknya dua dekade ini tentang bahaya dan manfaatnya. Pemanfaatan bahan pangan dapat digunakan sebagai penangkal radikal bebas akibat radiasi pengion alami (radon). Tujuan; dari penelitian ini untuk menggambarkan tingkat pengetahuan orang tua SDN Arjasari akan pentingnya penangkal terhadap radiasi pengion alami (radon) yang telah diberi penyuluhan. Penelitian ini dilakukan pada orang tua siswa di SDN Arjasari dengan total sampel 106 subjek. Metode; yang digunakan deskriptif cross sectional dengan menggunakan kuesioner setelah penyuluhan. Hasil;yang didapat tingkat pengetahuan subjek mengenai bahan pangan dan kandungannya sebagai sumber antioksidan dan persepsi mengenai keadaan radiasi pengion alam (radon) menunjukkan baik sebesar 75,4\%, pengetahuan sedang sebesar 24,6\% dan tidak ada yang memiliki pengetahuan buruk. Kesimpulan; sebagian besar orang tua siswa SDN Arjassari dapat menerima pengetahuan terhadap radiasi pengion alami (radon) dan bahan pangan sebagai antioksidan.
\end{abstract}

Kata kunci: Antioksidan; Pengetahuan; Radiasi Pengion Alami(Radon).

\section{ABSTRACT}

Background; Perception and Radon's awareness has become a public and environmental health problem during this two decade about the dangers and benefits. Food can be used as a free radical preventive agent for radon. Purpose; this study was to discuss the level of knowledge parents of the importance of antioxidants towards radon which has been inspired. This study was conducted on parents of Arjasari Elementary School's students with a total sample of 106 subjects. Method; This studywas used descriptive cross sectional using a questionnaire after counseling. Result; The level of knowledge about food ingredients and sources as a source of antioxidants and perceptions of natural ionizing radiation (radon) showed good at $75.4 \%$, moderate knowledge at $24.6 \%$ and no one had bad knowledge .Conclusions; Mostly, there has 
an influence the parentsknowledge of SDN Arjassari students towards natural ionizing radiation (radon) and food ingredients as antioxidants.

Keywords: Antioxidant; Knowledge; Natural Background Radiation(Radon).

\section{PENDAHULUAN}

SDN Arjasari merupakan sekolah dasar yang bertepatan di kecamatan Arjasari yang merupakan daerah berbukit-bukit di tengah kabupaten Bandung dan berada di kaki gunung Malabar (hulu Sungai Citarum). Kecamatan Arjasari merupakan daerah binaan UNPAD yang terdiri dari 11 desa dengan mayoritas masyarakat Arjasari bekerja sebagai petani dan buruh perkebunan. Keadaan geografis Arjasari berbukit yang membutuhkan kelestarian lingkungan yang baik. Menurut data setempat, kondisi lingkungan Arjasari mulai diliputi banjir dan longsor dikarenakan pembangunan dan kurangnya menjaga kelestarian lingkungan (Azhari et al., 2017; Susilawati, Damayanti and Rizky, Ivhatry, azhari, 2017; Wicaksono et al., 2018). Desa Arjasari juga masih rendah tingkat pengetahuan untuk mengolah diversitas sektor selain jagung seperti gandum yang dapat diolah menjadi komoditas di daerah Arjasari.

Jagung dan gandum mengandung serat pangan yang berguna sebagai dietary fiber dan antioksidan yang dapat menghambat atau memperlambat kerusakan dalam tubuh. (Suarni dan Herman Subagio B, 2014) Fungsi antioksidan sebagai peningkatan sistem kekebalan, pengatur tekanan darah, penurunan kadar kolesterol, serta pengatur kadar gula darah.(Sayuti and Yenrina, 2015) Antioksidan bekerja dengan cara mendonorkan satu elektronnya kepada senyawa yang bersifat oksidan sehingga aktivitas senyawa oksidan tersebut dapat di hambat.Antioksidan dibutuhkan tubuh untuk melindungi tubuh dari serangan radikal bebas. Salah satu penyebab adanya radikal bebas yaitu berasal dari radiasi. (Kumar, 2011; Sayuti and Yenrina, 2015; Devi, 2017) Radiasi dapat bersifat buatan dan alami. Radiasi yang bersifat alami berasal dari alam yang memberikan kontribusi besar terhadap kesehatan (Stuart C. White, 2004).

Desa Arjasari merupakan kawasan agribisnis yang dapat menghasilkan bahan makanan kebutuhan pokok akan tetapi tidak akan terlepas dari sumber radiasi alam (Kehutanan, 2015). Radon adalah salah satu radiasi alam yang berasal dari peluruhan bebatuan dan berasal dari tanah 
yang mempunyai unsur tidak berbau, tidak berwarna dan tidak berasa dan penyumbang radiasi alam terbesar di bumi sebanyak $80 \%$ (Stuart C. White, 2004). Paparan radiasi ini dapat menyebabkankanker paru paru pada sebagian besar penduduk dunia (Li et al., 2012). Hal ini dikarenakan adanya risiko yang ditimbulkan oleh radiasi pengion alam (radon) terhadap kesehatan dan dalam jangka panjang dan pada akhirnya akan berdampak pada kualitas hidup (Quality of Life/QoL) (WHO, 2009). Kesadaran dan persepsi radon telah menjadi masalah kesehatan publik dan lingkungan selama setidaknya dua dekade ini tentang bahaya dan manfaatnya (Hall and Nwako, 2016).

Penerapan konsep pendidikan didalam bidang kesehatan merupakan salah satu upaya dalam promosi kesehatan yang akan diberikan stimulus berupa informasi kemudian akan diproses menghasilkan pengetahuan yang akan direspon melalui sikap (Soekidjo, 2010). Akan tetapi, pengetahuan akan bahaya dari radiasi alam (radon) dan penanganannya belum bayak diketahui oleh masyarakat (Redden, 2014). Salah satu metode untuk menyebarluaskan bahaya paparan radiasi radon dan penanganannya dengan melakukan promosi kesehatan. Promosi kesehatan ini dapat digunakan agar lebih menjamin peningkatan pengetahuan yang dapat mempengaruhi sikap dan perilaku seseorang (Kumar and Preetha, 2012).Tujuan dari penelitian ini adalah untuk menggambarkan tingkat pengetahuan masyarakat akan pentingnya antioksidan terhadap radiasi pengion alami (radon) pada daerah Arjasari Kecamatan Arjasari Kabupaten Bandung.

\section{METODE DAN BAHAN}

Penelitian ini menggunakan penelitian deskriptif cross sectional tentang pengetahuan radiasi pengion alam dan antioksidan yang diperlukan oleh tubuh yang telah mendapat persetujuan etik dari Komisi Etik Penelitian Kesehatan UNPAD No. 0817090970. Penelitian ini dilakukan pada bulan Oktober 2017 di SDN Desa Arjasari Kabupaten Bandung. Penelitian ini melakukan penyuluhan dengan media power point dan cceramah interaktif. Mengingat penyuluhan merupakan proses edukasi yang perlu diukur keberhasiannya, maka dilakukan proses evaluasi setelah penyuluhan dengan menggunakan kuisioner. Selanjutnya dilakukan analisis untuk melihat efektivitas proses edukasi. Pengumpulan Data dilakukan melalui wawancara dengan menggunakan kuesioner terhadap orang tua. Pemilihan subjek dilakukan dengan 
consecutive sampling. Subjek penelitian adalah orang tua siswa SDN Desa Arjasari Kabupaten Bandungyang bermatapencaharian sebagai petani. Subjek penelitian ini adalah masyarakat yang berdomisili di Desa Arjsari dan menyekolahkan anaknya di SDN 1 Arjsari Kecamatan Arjasari Kabupaten Bandung. Informasi yang digali merupakan pengetahuan subjek mengenai komoditas pangan (jagung dan gandum) yang dapat menjadi sumber antioksidan yang dapat diolah dan pengetahuan radiasi pengion alami.Kriteria inklusi pada penelitian ini adalah: peserta yang bisa membaca dan menulis bekerja sebagai petani dan merupakan orang tua siswa SD Arjasari Desa Arjasari Kabupaten Bandung yang mendapatkan penyuluhan mengenai radiasi pengion radon dan antioksidan. Kriteria eksklusi pada penelitian ini adalah orang tua siswa yang tidak mau menandatangai informed consentdan tidak datang ke SDN Arjasari. Sebelumnya responden diminta untuk kesediaan dan diminta informed consent terkait menjadi subjek penelitian. Responden di berikan kuesioner berupa pertanyaan tertutup sesudah penyuluhan. Lembar kuesioner berisi daftar pertanyaan yang mengacu pada konsep dan teori yang disusun secara terstruktur mengenai materi yang telah disampaikan sehingga responden dapat memberikan jawabannya. Data yang diperoleh akan diuji dengan menggunakan uji validitas dan reliabilitas. Data juga akan diuji dengan menggunakan uji normalitas. Apabila menggunakan kuesioner, maka kuesioner yang digunakan merupakan kuesioner yang telah teruiji validitas dan reliabitiasnya.

Tabel 1. Kisi-kisi instrumen kuesioner

\begin{tabular}{llc}
\hline \multirow{2}{*}{ Konstrak } & \multicolumn{1}{c}{ Faktor indikator } & $\begin{array}{c}\text { Nomor } \\
\text { item }\end{array}$ \\
\hline $\begin{array}{l}\text { Antioksidan dan } \\
\text { radiasi alam }\end{array}$ & $\begin{array}{l}\text { Pengertian antioksidan dan } \\
\text { radiasi pengion alami (radon) }\end{array}$ & $1-5$ \\
\cline { 2 - 3 } & $\begin{array}{l}\text { Jenis-Jenis Antioksidan yang } \\
\text { menjadi sumber pangan dan } \\
\text { komoditas di Desa Arjasari } \\
\text { (Jagung dan Gandum) }\end{array}$ & \\
\cline { 2 - 3 } & $\begin{array}{l}\text { Bahaya radiasi pengion alami } \\
\text { (radon) }\end{array}$ & $11-15$ \\
\cline { 2 - 3 } & $\begin{array}{l}\text { Penangana n Radiasi Pengion } \\
\text { alami Radon akibat kerusakan }\end{array}$ & $15-20$ \\
\hline
\end{tabular}

\section{HASIL DAN PEMBAHASAN}

Orang tua memiliki hak dan kewajiban dalam pendidikan, memperoleh informasi tentang perkembangan pendidikan anaknya, serta memberikan masukan kepada tenaga pendidik. Orang tua yang terlibat aktif dalam penyelenggaraan pendidikan di sekolah akan menciptakan pendidikan yang lebih efektif untuk meningkatkan taraf hidup dan tingkat kesejahteraan dapat diukur melalui beberapa 
indikator diantaranya terpenuhinya gizi dan tingginya pendidikan yang disesuaikan dengan pembukaan UUD 1945 yakni melindungi seluruh bangsa dan tumpah darah Indonesia, memajukan kesejahteraan umum, dan mencerdaskan kehidupan bangsa dan ikut melaksanakan ketertiban dunia berdasarkan kemerdekaan, perdamaian abadi dan keadilan sosial(Kementrian Pendidikan Dan Kebudayaan, 2015). BerdasarkanTabel 2 dengan total sampel 106 orang tua siswa menunjukan bahwa mayoritassubjek yang datang adalah perempuan (97.2\%). Hal ini dikarenakan pada penelitian ini subjek terbanyak bekerja sebagai ibu rumah tangga sehingga bisa menyempatkan diri untuk mengikuti penelitian ini daripada laki-laki yang lebih sibuk bekerja di luar. Rata-rata umur yang paling banyak 17-35 tahun (60.38\%) dengan pendidikan terakhir yang paling banyak adalah SMA (59.43\%) dibandingkan dengan SMP dan kuliah.

Tabel 2. Distribusi demografik variabel subjek $(n=106)$

\begin{tabular}{lccc}
\hline \multicolumn{1}{c}{ Variabel } & & Frekuensi & presentasi \\
\hline Umur & $17-35$ & 64 & 60.38 \\
& $36-54$ & 28 & 26.42 \\
& $54-72$ & 14 & 13.20 \\
gender & perempuan & 103 & 97.12
\end{tabular}

\begin{tabular}{lccc}
\hline \multicolumn{1}{c}{ Variabel } & & Frekuensi & presentasi \\
\hline & Laki-laki & 3 & 2.8 \\
$\begin{array}{l}\text { Pendidikan } \\
\text { terakhir }\end{array}$ & SD & 1 & 0.94 \\
& SMP & 31 & 29.25 \\
& SMA & 63 & 59.43 \\
& Kuliah & 11 & 10.38 \\
total & & 106 & $100 \%$ \\
\hline
\end{tabular}

Pencapaian dalam program ini dapat dinilai secara kuantitatif, yaitu dengan memberikan Berdasarkan Tabel 3tingkat pengetahuan subjek mengenai bahan pangan dankandungannya sebagai sumber antioksidan dan persepsi mengenai keadaan radiasi pengion alam (radon) menunjukan cukup (24.6\%) dan tinggi (75.4\%).

Tabel 2. Rekapitulasi responden terhadap instrumen kuesioner

\begin{tabular}{|c|c|c|c|}
\hline Variabel & Pertanyaan & Jawaban & Frekuensi \\
\hline \multirow[t]{2}{*}{1} & $\begin{array}{l}\text { Apakah jagung } \\
\text { dan gandum }\end{array}$ & Ya & 101 \\
\hline & $\begin{array}{l}\text { sebagai antioksidan } \\
\text { diperlukan oleh } \\
\text { tubuh? }\end{array}$ & Tidak & 5 \\
\hline \multirow[t]{2}{*}{2} & Apakah antioksidan & Ya & 96 \\
\hline & pemeliharaan tubuh? & tidak & 16 \\
\hline \multirow[t]{2}{*}{3} & $\begin{array}{l}\text { Apakah Radiasi } \\
\text { pengion alami (radon) }\end{array}$ & ya & 100 \\
\hline & $\begin{array}{l}\text { dapat berada di } \\
\text { sekitar kita? }\end{array}$ & Tidak & 6 \\
\hline \multirow[t]{2}{*}{4} & $\begin{array}{l}\text { Apakah Antioksidan } \\
\text { dapat menangkal }\end{array}$ & Ya & 100 \\
\hline & $\begin{array}{l}\text { radiasi pengion alami } \\
\text { (radon)? }\end{array}$ & tidak & 6 \\
\hline \multirow[t]{2}{*}{5} & Apakah radon dapat & Ya & 93 \\
\hline & & Tidak & 13 \\
\hline
\end{tabular}


ISSN: 1858-3385, EISSN: 2549-7006

GASTER Vol. 17 No. 2 Agustus 2019

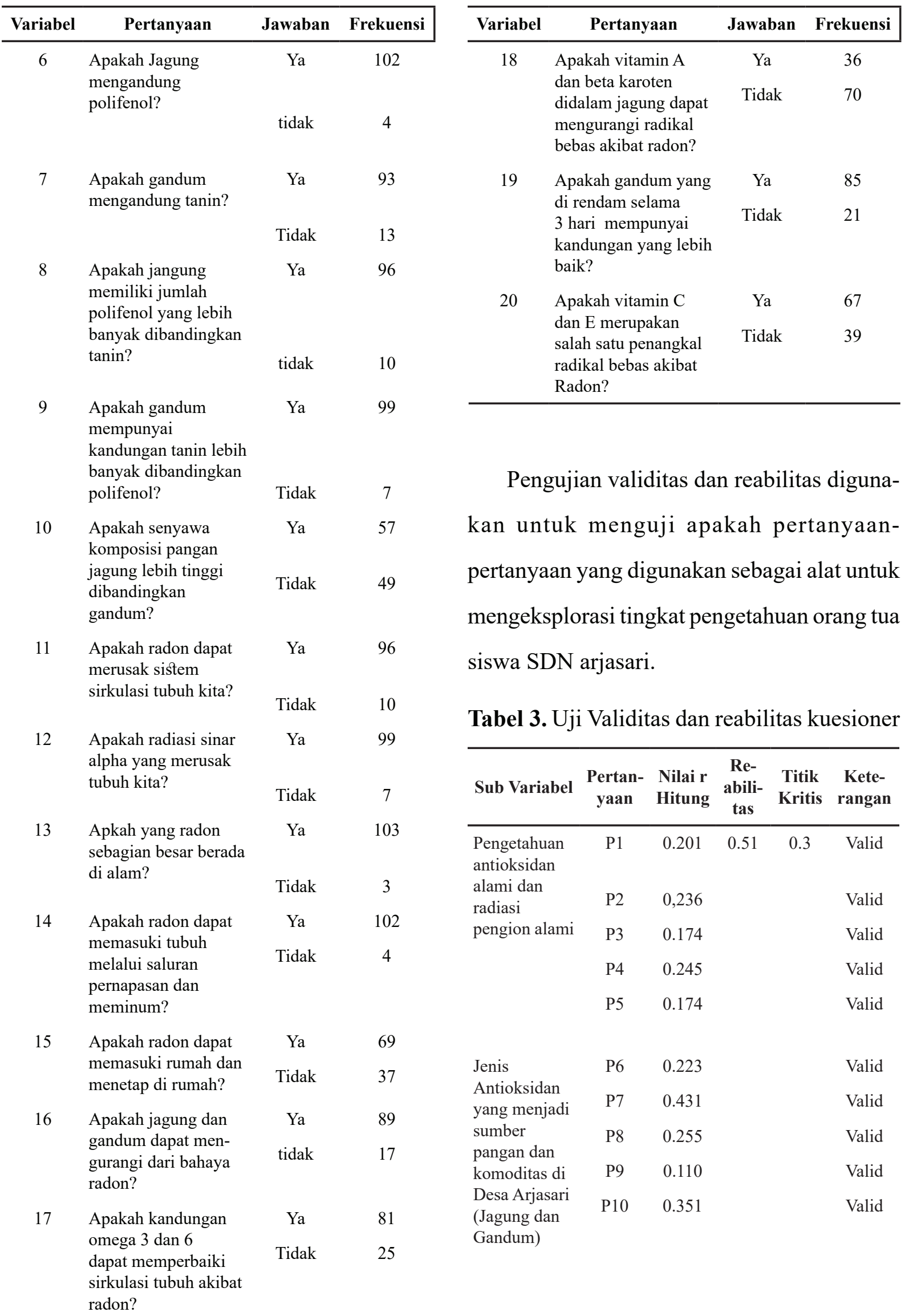




\begin{tabular}{|c|c|c|c|c|c|}
\hline Sub Variabel & $\begin{array}{c}\text { Pertan- } \\
\text { yaan }\end{array}$ & $\begin{array}{l}\text { Nilai r } \\
\text { Hitung }\end{array}$ & $\begin{array}{c}\text { Re- } \\
\text { abili- } \\
\text { tas }\end{array}$ & $\begin{array}{c}\text { Titik } \\
\text { Kritis }\end{array}$ & $\begin{array}{l}\text { Kete- } \\
\text { rangan }\end{array}$ \\
\hline \multirow{4}{*}{$\begin{array}{l}\text { Bahaya } \\
\text { radiasi } \\
\text { pengion alami } \\
\text { (radon) }\end{array}$} & P11 & 0.236 & & & Valid \\
\hline & P12 & 0.434 & & & Valid \\
\hline & P13 & 0.251 & & & Valid \\
\hline & P14 & 0.347 & & & Valid \\
\hline \multirow{6}{*}{$\begin{array}{l}\text { Penangana } \\
\text { n Radiasi } \\
\text { Pengion } \\
\text { alami Radon } \\
\text { akibat } \\
\text { kerusakan }\end{array}$} & P15 & 0.209 & & & Valid \\
\hline & P16 & 0.336 & & & Valid \\
\hline & P17 & 0.387 & & & Valid \\
\hline & P18 & 0.136 & & & Valid \\
\hline & P19 & 0.136 & & & Valid \\
\hline & P20 & 0.381 & & & Valid \\
\hline
\end{tabular}

Berdasarkan jumlah jawaban menunjukkan efektivitas pendidikan yang telah dilakukan dalam meningkatkan pengetahuan orang tua siswa. Nilai rata-rata tingkat pengetahuan subjek menunjukkan ketidakpatuhan dengan jumlah yang lebih besar. Berdasarkan uji-t yang telah dilakukan, nilai P (Sig.) Adalah 0.001 , yang berarti kurang dari $0.05(\mathrm{p}<0.05)$. Jadi bisa dikatakan pengetahuan tentang radiasi pengion alami (radon)dan antioksidan dapat mempengaruhi tingkat pengetahuan subjek.

Sistem penilaian atau pemahaman tergantung pada representasi mental kolektif dan individu, dan dapat berbeda dari waktu ke waktu. Persepsi risiko lingkungan diartikan sebagai konstruksi sosial dan bukan sebagai bahan objektif dari bahayanya lingkungan
(Jones et al., 2013). Abramson, Barkanova\& Redden (2014) menemukan bahwa adanya korelasi positif antara pengetahuan dan persepsi radon dengan bahaya terhadap kesehatan yang dihubungkan dengan tingkat pendidikan (Redden, 2014). Hal ini juga sejalan dengan penelitian sebelumnyabahwa kurangnya informasi radon dapat memicu masalah lingkungan (Poortinga, Bronstering and Lannon, 2011).

Lokasi geografis juga ditemukan sebagai faktor penting bagi kesadaran, persepsi, dan perilaku orang yang berhubungan dengan radon dan antioksidan. Salah satu komoditas daerah Arjasari adalah jagung dan gandum yang dapat dimamfaatkan dan diolah sebagai sumber pangan yang dapat digunakan sebagai antioksidan terhadap paparan lingkungan(Lobo et al., 2010; Suarni dan Herman Subagio B, 2014). Jagung dan gandum dapat dikatakan sebagai Neutraceutical dimana terdapat kandungan didalamnya yang berfungsi sebagai penangkal radikal bebasatau dapat sebagai suplemen atau produk sereal yang menjadi sumber makanan pokok (Lobo et al., 2010). Oleh karena itu diperlukan pengetahuan antioksidan yang berasal dari sumber pangan sebagai penangkal radikal bebas akibat radiasi pengion alami (radon). 
Pengetahuan akan mempengaruhi sikap dan perilaku seseorang karena apabila pengetahuan baik maka cenderung untuk bersikap dan perilaku yang positif. Apabila sikap dan perilaku seseorang sudah baik maka akan berdampak baik juga pada keadaan kesehatannya. Sebaliknya pengetahuan yang cukup dan sikap yang baik diperlukan untuk menumbuhkan perilaku yang bersifat konsisten (Onasoga et al., 2015).

Pengetahuan sangat erat kaitannya dengan pendidikan dimana diharapkan seseorang dengan pendidikan tinggi, maka orang tersebut akan semakin luas pula pengetahuannya. Namun perlu ditekankan bahwa seorang yang berpendidikan rendah tidak berarti mutlak berpengetahuan rendah pula. Peningkatan pengetahuan tidak mutlak diperoleh di pendidikan formal, akan tetapi juga dapat diperoleh pada pendidikan non formal.

Perilaku hidup sehat pada dasarnya dibentuk melalui respon seseorang terhadap stimulus yang berkaitan dengan lingkungan. (Azhariet al., 2017) (Soekidjo, 2010). Lingkungan adalah salah satu faktor yang mempengaruhi kesehatan manusia (Notosiswoyo, 2014). Salah satu usaha yang dilakukan manusia untuk menjaga kesehatan masyarakat supaya dapat mencapai derajat kesehatan yang optimal adalah dengan merubah lingkungan hidup menjadi lingkungan yang bersih(WHO, 2009). Faktor ini akan bertahan lama jika suatu perilaku didasari pengetahuan dan kesadaran. Pengetahuan, pikiran, keyakinan memegang peranan penting dalam menentukan sikap dan diperlukan suatu kondisi yang memungkinkan yakni fasilitas dan dukungan.

Pengetahuan diperoleh baik dari pengalaman langsung maupun pengalaman dari orang lain. Pengetahuan dapat diperoleh dari suatu kegiatan penyuluhan. Penyuluhan merupakan proses suatu kegiatan pemberian informasi tentang hidup sehat untuk mengubah perilaku masyarakat. Penyuluhan merupakan salah satu strategi untuk memperoleh perubahan perilaku untuk meningkatkan pengetahuan sehingga menimbulkan kesadaran dan dapat dilakukan dengan pemberian penyuluhan kesehatan (Kumar and Preetha, 2012). Beberapa faktor lainnya yang dapat mempengaruhi derajat pengetahuan yaitu Umur. Umur merupakan salah satu faktor yang dapat menentukan kematangan berfikir bertindak maupun belajar. Subjek pada usia diatas sudah termasuk usia yang matang dalam menjalankan perannya dan sudah dapat menerima informasi yang diperoleh. 
Semakin bertambah usia seseorang maka bertambah informasi yang didapat (Soekidjo, 2010; Lely Suratri, Sintawati and Andayasari, 2016). Faktor pengetahuan lain yang dapat mempengaruhi tingkat berfikir seseorang adalah tingkat pendidikan.Tingkat pendidikan mempengaruhi kesadaran akan pentingnya arti kesehatan baik pada dirisendiri maupun pada lingkungan yang mendorong kebutuhan akan pelayanan kesehatan (Soekidjo, 2010). Menurut Notoatmodjo, tujuan pendidikan adalah untuk mengembangkan dan meningkatkan pendidikan. Menurut Departemen Kesehatan 2003 bahwa kategori pendidikan seseorang bila sudah menjalani lebih dari 9 tahun masa pendidikan (Kementrian Pendidikan Dan Kebudayaan, 2015). Pengetahuan orang tua sangat penting dalam mendasari terbentuknya perilaku yang mendukung atau tidak mendukung pengetahuan anak. Pengetahuan tersebut dapat diperoleh secara alami maupun secara terencana yaitu melalui proses pendidikan. Hal ini didukungTeori aktivitas L. Green, yaitu pengetahuan merupakan faktor internal yang terdapat dalam diri individu sehingga dapat mempermudah individu untuk berprilaku dan pengetahuan berpengaruh langsung terhadap sikap dan perilaku seseorang (Soekidjo, 2010).

\section{KESIMPULAN DAN SARAN}

Berdasarkan hasil penelitian tentang Pengetahuan orang tua siswa tentang antioksidan dan radiasi pengion alami (radon) di Desa Arjasari Kabupaten Bandung, maka disimpulkan bahwa sebagian besar dapat menyerap pengetahuan dari penyuluhan tentang antioksidan dan radiasi pengion alami (radon) dan tidak ada yang memiliki pengetahuan buruk. Berdasarkan hasil dan pembahasan yang dilakukan, maka disarankan untuk dilakukan penelitian tentang hubungan tingkat pengetahuan orang tua siswa dengan penerapan pengolahan bahan pangan yang menjadi sumber antioksidan alami dan radiasi pengion alami radon sehingga diperoleh peningkatan kualitas hidup.

\section{DAFTAR PUSTAKA}

Azhari et al. (2017) 'Knowledge level of the elementary school of Arjasari students after education regarding natural background radiation and oral health care', Padjadjaran Journal of Dentistry, 29(3), pp. 172-176. 
ISSN: 1858-3385, EISSN: 2549-7006

GASTER Vol. 17 No. 2 Agustus 2019

Devi, G. (2017) 'Research Article A Survey on General Awareness among People about the Role of Antioxidants in Health', 44 (13), pp. 49-51.

Hall, S. and Nwako, P. (2016) Exploring Knowledge, Beliefs and Practices of Radon Gas Exposure Among Public Health Workers. Seton Hall University Dissertation and Theses (ETDs).2232.

Jones, E. C. et al. (2013) 'Cross-Cultural and Site-Based Influences on Demographic, Wellbeing, and Social Network Predictors of Risk Perception in Hazard and Disaster Settings in Ecuador and Mexico: Predictors of Risk Perception in Hazard and Disaster Settings in Ecuador and Mexic', Human Nature, 24(1), pp. 5-32.

Kehutanan, P. daerah kabupaten bandung dan dinas pertanian perkebunan dan (2015) Laporan Tahunan Kabupaten Bandung 2015. kabupaten bandung.

Kementrian Pendidikan Dan Kebudayaan (2015) Rencana Strategis Kementrian Pendididkan Dan Kebudayaan 2015-2019. Jakarta.

Kumar, S. (2011) 'Free Radicals and Antioxidants: Human and Food System', Advances in Applied Science Research, 2(1), pp. 129-135.

Kumar, S. and Preetha, G. (2012) 'Health promotion: An effective tool for global health', Indian Journal of Community Medicine, 37(1), p. 5.

Lely Suratri, M. A., Sintawati, F. and Andayasari, L. (2016) 'Pengetahuan, Sikap, dan Perilaku Orang Tua tentang Kesehatan Gigi dan Mulut pada Anak Usia Taman Kanak-kanak di Provinsi Daerah Istimewa Yogyakarta dan Provinsi Banten Tahun 2014', Media Penelitian dan Pengembangan Kesehatan, 26(2), pp. 119-126.

Li, B. Y. et al. (2012) 'Radon-induced reduced apoptosis in human bronchial epithelial cells with knockdown of mitochondria DNA', Journal of Toxicology and Environmental Health - Part A: Current Issues, 75(18), pp. 1111-1119.

Lobo, V. et al. (2010) 'Free radicals, antioxidants and functional foods: Impact on human health', Pharmacognosy Reviews, 4(8), p. 118.

Notosiswoyo, M. (2014) 'Pengetahuan, Sikap dan Perilaku Siswa SLTA dalam Pencegahan Kecelakaan Sepeda Motor di Kota Bekasi’, Jurnal Ekologi Kesehatan, 13(1), pp. 1-9.

128 Pengetahuan Orang Tua terhadap Antioksidan dan .... 
Onasoga, O. et al. (2015) 'Midwives' knowledge and utilization of non-pneumatic anti shock garment in reducing complication of postpartum haemorrhage in selected health care facilities in Bayelsa state Nigeria', International Journal of Reproduction, Contraception, Obstetrics and Gynecology, 4(4), pp. 977-981.

Poortinga, W., Bronstering, K. and Lannon, S. (2011) 'Awareness and perceptions of the risks of exposure to indoor radon: A population-based approach to evaluate a radon awareness and testing campaign in England and Wales', Risk Analysis, 31(11), pp. 1800-1812.

Redden, A. (2014) 'Concerning Knowledge: Assessing Radon Knowledge and Concern in Rural Nova Scotia', journal of rural and comunity development, 9(2), pp. 103-111.

Sayuti, K. and Yenrina, R. (2015) Antioksidan Alami dan Sintetik. 1st edn, Andalas University Press. 1 st edn. Edited by P. D. Tuty Anggraini, STP, MP and D. F. Safri. Padang Indonesia: Andalas University Press.

Soekidjo, N. (2010) 'Promosi Kesehatan Teori dan Aplikasi Edisi Revisi.', p. 325.

Stuart C. White, M. J. P. (2004) 'Oral Radiology Principles and Interpretation', Mosby, 5th editio(9), pp. 1689-1699.

Suarni dan Herman Subagio B (2014) 'Potensi Pengembangan Jagung Dan Sorgum Sebagai Sumber Pangan Fungsional', jurnal litbang pertanian, 32(juni 2013), pp. 47-55.

Susilawati, S., Damayanti, M. A. and Rizky, Ivhatry, azhari, S. (2017) 'Pengaruh Penyuluhan Terhadap Tingkat Pengetahuan Siswa Tentang Kesehatan Gigi Dan Mulut Yang Dipengaruhi Radiasi’, Jurnal Pengabdian Kepada Masyarakat, 1(6), pp. 398-401.

WHO (2009) 'Who Handbook on Indoor Radon - A Public Health Perspective', World Health Organization. doi: 10.1080/00207230903556771.

Wicaksono, F. Y. et al. (2018) 'Respons Masyarakat Terhadap Pengenalan Tanaman Gandum Dan Produk- Produknya Di Desa Arjasari Kecamatan Arjasari Kabupaten Bandung', Dharmakarya jurnal aplikasi Iptek untuk masyarakat, 7(1), pp. 32-37. 